\title{
Surface polymers of the nematode-trapping fungus Arthrobotrys oligospora
}

\author{
ANDERS TUNLID, ${ }^{*}$ TOMAS JOHANSSON ${ }^{2}$ and Birgit NORDBRING-HerTZ ${ }^{3}$ \\ ${ }^{1}$ Department of Chemical Ecology and Ecotoxicology, Lund University, Ecology Building, Helgonavägen 5, \\ S-223 62 Lund, Sweden \\ ${ }^{2}$ Department of Biochemistry, Chemical Center, Lund University, Box 124, S-221 00 Lund, Sweden \\ ${ }^{3}$ Department of Microbial Ecology, Lund University, Ecology Building, Helgonavägen 5, S-223 62 Lund, Sweden
}

(Received 29 November 1990; accepted 13 February 1991)

\begin{abstract}
The nematophagous fungus Arthrobotrys oligospora captures nematodes using adhesive polymers present on special hyphae (traps) which form a three-dimensional network. To understand further the adhesion mechanisms, A. oligospora surface polymers were visualized by transmisson electron microscopy and characterized by chemical methods. Both traps and hyphae were surrounded by a fibrillar layer of extracellular polymers which stained with ruthenium red. The polymer layer was resistant to most of the chemicals and enzymes tested. However, part of the layer was removed by sonication in a Tris-buffer or by extraction in a chaotropic salt solution (LiCl), and the structure of the polymers was modified by treatment with Pronase E. Chemical analysis showed that the crude extracts of surface polymers removed by sonication or $\mathbf{~ L i C l ~ s o l u t i o n ~ c o n t a i n e d ~ n e u t r a l ~ s u g a r s , ~ u r o n i c ~ a c i d s ~ a n d ~}$ proteins. Gel chromatography of the extracts revealed that the major carbohydrate-containing polymer(s) had a molecular mass of at least $100 \mathrm{kDa}$, containing neutral sugars $(75 \%$ by weight, including glucose, mannose and galactose), uronic acids (6\%) and proteins (19\%). There was more polymer in mycelium containing trap-bearing cells than in vegetative hyphae. SDS-PAGE of the extracted polymers showed that the trap-forming cells contained at least one protein, with a molecular mass of approx. $32 \mathrm{kDa}$, not present on vegetative hyphae. Examining the capture of nematodes by traps of $A$. oligospora in which the layer of surface polymers was modified, or removed by chemical or enzymic treatments, showed that both proteins and carbohydrate surface polymers were involved in the adhesion process.
\end{abstract}

\section{Introduction}

Adhesion of fungi to surfaces is considered to be an important event in the colonization and pathogenesis of humans, animals and plants (Nicholson \& Epstein, 1990; Kennedy, 1990). Adhesion might be involved in the recognition of the host, in the firm binding of the pathogen to the host surface, and in serving as the site for penetration and start of the infection of the host cells. In contrast to the adhesion mechanisms of pathogenic bacteria, these processes have not been well characterized in fungi. No fungal surface molecules mediating adhesion to surfaces have been described in detail, and the molecular interactions between such compounds and the host surface are not understood.

Numerous electron microscopic studies suggest that adhesion of fungi to surfaces is mediated by extracellular polymers (EP) (Gold \& Mendgen, 1984; Latgé et al., 1986; Veenhuis et al., 1985; Mims \& Richardson, 1989;
Onyile et al., 1982; Hyde \& Jones, 1989). According to these studies, the structure of such polymers varies from amorphous liquids to fibrillar polymers, and cytochemical and chemical analysis indicates that EP layers consist of polysaccharides and/or proteins or glycoproteins. Similar kinds of polymers have also been found in fungal structures not involved in adhesion to surfaces (Wessels \& Sietsma, 1981), which suggests that they might have other functions as well (Nicholson \& Epstein, 1991). A few studies have shown that the ultrastructure of surface polymers can change during adhesion. Gymnosporangium juniperi-virginianae basidiospore germlings produce a diffuse, filamentous network of material that subsequently changes to an electron-dense layer binding the entire germling to the host surface (Mims \& Richardson, 1989). The adhesion of Candida albicans to epithelial cells appears to involve spatial rearrangements of their cell wall surface (Tronchin et al., 1984). However, the chemical interactions between the 
fungus EP layer and the host surface, and the chemical changes occurring during the adhesion, are not known.

The adhesion of nematodes to the nematophagous fungus Arthrobotrys oligospora is a well-studied model system for examining the molecular mechanisms of fungal adhesion to host surfaces (Nordbring-Hertz, 1988). This fungus captures nematodes using adhesive polymers present on special hyphae (traps), which form a three-dimensional network. Previous studies have demonstrated that the adhesion of nematodes to the traps is mediated by a lectin present in trap-containing mycelium (Nordbring-Hertz \& Mattiasson, 1979; Borrebaeck et al., 1984). Detailed EM studies have also shown that the cell walls of the traps are surrounded by an extracellular layer of fibrillar polymers, and that these fibrils become oriented in one direction during the first hour of capture (Veenhuis et al., 1985).

To understand further the molecular mechanisms of adhesion in this system, we have extracted and chemically characterized the components in the EP layer from both vegetative hyphae and mycelium containing traps of $A$. oligospora. The function of the components in the EP layer during adhesion was examined by studying the capture of nematodes to traps treated with various chemicals and enzymes shown to affect the chemical structure of the EP layer.

\section{Methods}

Culture of organisms. Arthrobotrys oligospora Fres. (ATCC 24927) was maintained on corn meal agar (CMA, Difco), supplemented with $2 \mathrm{~g} \mathrm{l}^{-1} \mathrm{~K}_{2} \mathrm{HPO}_{4}$. Liquid cultures of $A$. oligospora were obtained by inoculating $400 \mathrm{ml}$ or $4000 \mathrm{ml}$ media with a water suspension of conidia prepared from a 1-2 week old culture grown on CMA. Trap-containing mycelium $[\mathrm{T}(+)]$ was grown in a medium containing $0.01 \%$ soya peptone (neutralized, Oxoid) supplemented with $0.05 \mathrm{~g}$ phenylalanine and $0.05 \mathrm{~g}$ valine per litre (Friman et al., 1985). For the production of hyphae without traps $[\mathrm{T}(-)]$, the fungus was grown in the same medium but supplemented with $12 \mathrm{~mm}$-phosphate buffer $(\mathrm{pH} \mathrm{7 \cdot 0)}$. Mycelia used for the extraction of surface polymers from $\mathrm{T}(+)$ and $\mathrm{T}(-)$ cultures were harvested by filtering through a nylon mesh. The mycelia were then washed with $5 \times 10 \mathrm{ml}$ of ice-cold $\left(4^{\circ} \mathrm{C}\right)$ distilled water or buffer. For the adhesion bioassay, a conidial suspension of $A$. oligospora was inoculated onto dialysis membranes, which were placed on agar plates supplemented with low-nutrient medium (LNM) and phenylalanyl-valine (Nordbring-Hertz, 1973).

The nematode Panagrellus redivivus (Goodey) was grown axenically in a soya-peptone-liver extract medium (Nordbring-Hertz, 1977). The nematodes were washed extensively with distilled water before being used in the adhesion assays.

Transmission electron microscopy (TEM). Treated and untreated mycelia were stained with ruthenium red (Fluka AG, Buchs, Switzerland) as described by Luft (1971) and modified by Handley et al. (1988). Control samples were prepared by substituting distilled water for ruthenium red solutions. After dehydrating the samples in a graded series of ethanol and water, they were embedded in Polarbed (Johnsson
Lab System, Solna, Sweden), cut on a Reichert-Jung Supernova ultramicrotome, and examined in a Jeol $100 \mathrm{CX}$ electron microscope (located at the Electron Microscopy Unit, Faculty of Medicine, Lund University).

Extraction of surface polymers. Washed $\mathrm{T}(+)$ and $\mathrm{T}(-)$ mycelia from the liquid cultures were transferred to $50 \mathrm{ml}$ flasks, $10 \mathrm{ml}$ of the solutions used for the extractions was added, and the flasks were incubated on a rotary shaker. The following solutions and conditions were used to extract the surface polymers. (1) A chaotropic salt solution containing $1 \mathrm{M}$ - or $5 \mathrm{M}-\mathrm{LiCl}$ in a $10 \mathrm{~mm}$-Tris/ $\mathrm{HCl}$ buffer $(\mathrm{pH} 7 \cdot 4)$. The mycelia were extracted at $4{ }^{\circ} \mathrm{C}$ for $10 \mathrm{~min}$. This protocol is a modification of a procedure used to isolate surface polymers from the zygomycete Absidia glauca (Teepe et al., 1988). (2) A buffer containing the thiol reagent dithiothreitol (DTT) which dissociates disulphide bridges in proteins. The mycelia were extracted at $4{ }^{\circ} \mathrm{C}$ for $10 \mathrm{~min}$ in $12 \mathrm{~mm}$-DTT and $20 \mathrm{~mm}$-Tris/HCl buffer $\mathrm{pH} \mathrm{7.4}$. Buffers with DTT have been used to extract surface polymers from Candida sp. (Chattaway et al., 1974; Ponton \& Jones, 1986). (3) A 0.1 M-sodium phosphate buffer (pH 6.5) containing urea ( $8 \mathrm{M})$, mercaptoethanol $(1 \%$, $\mathrm{v} / \mathrm{v})$ and sodium dodecyl sulphate (SDS) $(1 \% \mathrm{w} / \mathrm{v})$. The mycelia were extracted at room temperature for $4 \mathrm{~h}$. Buffers with urea, mercaptoethanol and SDS have been used in numerous studies to extract proteins from fungal cell walls (Wu-Yuan \& Hashimoto, 1977; Chaffin \& Stocco, 1983). (4) Sonication at $4{ }^{\circ} \mathrm{C}$ in a $20 \mathrm{~mm}$-Tris $/ \mathrm{HCl}$ buffer (pH 7.5). The mycelia were first mixed in $10 \mathrm{ml}$ Tris buffer with an Ultra-Turrax homogenizer (type T 18/10; Janka Kunkel, IKA) for $10 \mathrm{~s}$, followed by sonication (Bransonic $220 \mathrm{unit}$ ) for $20 \mathrm{~s}$. The mycelia were centrifuged $(5000 \mathrm{~g}, 20 \mathrm{~min})$ and the supernatants retained for chemical analysis. The sonication and centrifugation steps were repeated twice with $2 \times 10 \mathrm{ml}$ Tris buffer. Sonication in water or buffer solutions has been used to extract cell wall polymers from Aspergillus nidulans (Claverie-Martin et al., 1986) and from Neurospora crassa (Beever et al., 1979). (5) Cold $\left(4^{\circ} \mathrm{C}\right) 0 \cdot 1 \mathrm{M}-\mathrm{NaOH}$ for $10 \mathrm{~min}$. Cold alkali has been used to extract cell wall proteins from a variety of fungi (Taylor \& Cameron, 1973).

After the incubations, the cultures were filtered through a nylon mesh. The mycelia were recovered and either prepared for TEM analysis, or lyophilized for dry weight measurements. Before chemical analysis, the polymer extracts were filtered $(0.22 \mu \mathrm{m})$ and concentrated by ultrafiltration using a Centriprep 10 or a Centricon 10 unit (Amicon Corp.).

Enzymic treatments. Washed mycelia of $\mathrm{T}(+)$ cultures were transferred to $10 \mathrm{ml}$ test tubes and incubated at $30^{\circ} \mathrm{C}$ with various enzymes. Pronase E (Merck) was used at a concentration of 2.9 or $0.3 \mathrm{mg} \mathrm{ml}^{-1}$ in a $10 \mathrm{~mm}$-Tris/ $\mathrm{HCl}$ buffer $(\mathrm{pH} \mathrm{7.4)}$ with an incubation time of $1 \mathrm{~h}$. Lyticase (Sigma, a $\beta(1,3)$-glucanase) at 2.7 or $0.3 \mathrm{mg} \mathrm{ml}^{-1}$; $\alpha$-mannosidase (EC 3.2.1.24, Sigma) at $1.0 \mathrm{mg} \mathrm{m}^{-1}$; chitinase (EC 3.2.1.14, Sigma) at $2.8 \mathrm{mg} \mathrm{m}^{-1}$; glucuronidase (EC 3.2.1.31, Sigma) at a final concentration of $5 \%(\mathrm{v} / \mathrm{v})$ corresponding to about 10000 Fishman Units and Novozym 234, a commercial preparation of Trichoderma harzianum enzymes (Novo Biolabs, Bagvaerd, Denmark) containing $\beta(1,3)$-glucanase and chitinase activity (Peberdy, 1985) were all incubated for $4 \mathrm{~h}$ in a $10 \mathrm{~mm}$-sodium phosphate buffer (pH 5.8). Control samples were treated with the corresponding buffer only. The incubations were stopped by transferring the test tubes to an ice-bath. The samples were centrifuged $\left(4^{\circ} \mathrm{C}, 5000 \mathrm{~g}, 20 \mathrm{~min}\right)$ and the supernatant discarded. The pellets were washed twice with water and prepared for TEM analysis.

Preparations of cell walls. To study whether the extracellular polymers could be recovered from prepared cell walls of $A$. oligospora, washed liquid-grown mycelia were mixed in an ice-cold $20 \mathrm{~mm}$-Tris/ $\mathrm{HCl}$ buffer (pH 7.5) with a Buhler mixer (Buhler, Tubingen) for $3 \times 60 \mathrm{~s}$. Following homogenization, the hyphal fragments were centrifuged 
$\left(4{ }^{\circ} \mathrm{C}, 5000 \mathrm{~g}, 20 \mathrm{~min}\right.$ ) and washed three times in the Tris-buffer. The final pellet was transferred to a test tube. Acid-washed glass beads $(0.5 \mathrm{~mm}$ diameter) were added and the test tube was agitated with a vortex mixer for $10 \times 30 \mathrm{~s}$. The glass beads were allowed to settle $\left(4^{\circ} \mathrm{C}\right)$ and the supernatants were recovered (Catley, 1988). The cell wall fragments were washed three times with $7 \mathrm{M}$-urea, $1.0 \mathrm{M}-\mathrm{NaCl}, 0.5 \mathrm{M}$ $\mathrm{NaCl}$, and distilled water.

Adhesion assay. A biological assay using a dialysis membrane technique (Nordbring-Hertz et al., 1984) was used to examine the effects of extracting the surface polymers from the traps on the capture of nematodes. Pieces of dialysis membranes $\left(1-2 \mathrm{~cm}^{2}\right)$ containing trapbearing mycelium (50-100 traps $\mathrm{cm}^{-2}$ ) were transferred to Petri dishes and incubated with the chemical solutions or enzymes used to extract polymers from the liquid-grown cultures. The concentrations and conditions were as described above. In one experiment the mycelia were treated with heat-denatured $\left(90{ }^{\circ} \mathrm{C}, 30 \mathrm{~min}\right)$ enzymes. Following the extractions, the membrane pieces were washed extensively with distilled water, or the appropriate buffer, and transferred to a new set of Petri dishes. The nematodes ( $20-30$ per membrane) were added, and captured, and free living nematodes were counted under a light microscope after $1 \mathrm{~h}$ and 20-22 $\mathrm{h}$ of interaction. The experiments were performed with 5-10 parallels and repeated at least twice. Controls consisted of trap-bearing mycelium washed with distilled water or the appropriate buffer. The statistical significance of the differences in frequencies of captured and free nematodes in treated samples versus controls were tested by $\chi^{2}$-analysis. The viability of $A$ oligospora after treating the mycelia with the extraction solutions and enzymes was examined by transferring one piece of the extracted membrane culture from each treatment to an agar plate with the LMN medium. The mycelia were incubated and the radial growth of the colonies was observed after 1-7 d.

Chemical analysis. Neutral sugars were estimated by the phenol/ sulphuric acid procedure (Dubois et al., 1956) using glucose as a standard. The carbazole assay (Bitter \& Muir, 1962) was used to determine the concentration of uronic acids, using glucuronolactone as a standard. Hexosamines were measured by the method of Elson \& Morgan (1933) using glucosamine as a standard. Proteins were determined by the method of Bradford (1976) using bovine albumin as a standard. The UV-VIS measurements were performed on a Hitachi U-3210 spectrophotometer.

Sugar composition. Monosaccharides were released by hydrolysis in $2 \mathrm{M}$-trifluoroacetic acid for $3 \mathrm{~h}$ at $110^{\circ} \mathrm{C}$ under nitrogen (Albersheim $e t$ al., 1967). Myo-inositol was added as an internal standard, and alditol acetates were prepared as described by Blakeney et al. (1983). The derivatives were determined by gas chromatography using a Hewlett Packard 5890 GC equipped with a capillary fused silica column $(30 \mathrm{~m} \times 0.2 \mathrm{~mm}$ i.d.) coated with a phenylmethyl silicone phase (DB-5, J\&W Scientific, Folsom, CA).

Gel chromatography. Surface polymers extracted with $5 \mathrm{M}-\mathrm{LiCl}$ or sonication in a Tris-buffer, were applied to a column of Sephacryl S-200 HR (Pharmacia, $1.5 \times 70 \mathrm{~cm}$ ) which had been equilibrated with $50 \mathrm{~mm}$-Tris/HCl buffer (pH 7.2) containing $1 \mathrm{M}-\mathrm{LiCl}$. The column was eluted with the same buffer at a flow rate of $0.5 \mathrm{ml} \mathrm{min}^{-1}$. Fractions of $3.0 \mathrm{ml}$ were collected. Fractions in peaks identified by analysis of neutral sugars were pooled and concentrated by ultrafiltration (Centriprep 10). The gel chromatography was performed at $4{ }^{\circ} \mathrm{C}$.

Pronase digestion. The method was that of Spiro (1966). A polymer extract, obtained from $\mathrm{T}(+)$ mycelium after sonication in $\mathrm{Tris} / \mathrm{HCl}$ buffer, was concentrated by ultrafiltration (Centriprep 10). Pronase E (Merck) was added at a concentration of about $30 \%$ of the estimated weight of glycoproteins, and the samples were incubated in test tubes at $30^{\circ} \mathrm{C}$ for $10 \mathrm{~h}$, then transferred to an ice-bath. The mixture was fractionated by gel chromatography as described above.
SDS-PAGE. Samples for gel electrophoresis were first desalted on a Sephadex G-25 Superfine (Pharmacia), packed into a HR 10/10 column, using $10 \mathrm{~mm}-\mathrm{NH}_{4} \mathrm{HCO}_{3}$ as the elution buffer. Samples of 1-2 $\mathrm{ml}$ were applied to the column and eluted at a flow rate of $2 \mathrm{ml} \mathrm{min}^{-1}$. The PhastSystem (Pharmacia) was used for electrophoresis and gel staining, and was performed according to the manufacturer's instructions. For SDS-PAGE, the PhastGel Gradient $8-25 \%$ and LMW Calibration Kit (Pharmacia) were used. The gels were stained with Coomassie Brilliant Blue. Molecular masses used for standard proteins were as follows: phosphorylase $b$ (rabbit), $97.4 \mathrm{kDa}$; bovine serum albumin, $66.0 \mathrm{kDa}$; ovalbumin, $45.0 \mathrm{kDa}$; carbonic anhydrase (bovine), $29.0 \mathrm{kDa}$; trypsin inhibitor (soybean), $20.1 \mathrm{kDa} ; \alpha$-lactalbumin, $14 \cdot 2 \mathrm{kDa}$.

\section{Results}

\section{Electron microscopy}

TEM showed that the adhesion of $A$. oligospora to the nematode $P$. redivivus was mediated by a layer of extracellular polymers staining with ruthenium red (Fig. $1 a$ ). The layer seemed to consist of densely packed fibrils. A layer of extracellular fibrils was also present on trap-forming cells without adhering nematodes (Fig. $1 b$ ) as well as on vegetative mycelium (not shown). The EP fibrils on these cells were more loosely packed than in the EP layer bridging the trap and nematode surfaces. Furthermore, the EP fibrils were not present in a uniform layer on the cell surface, but appeared to be more concentrated in areas of cell aggregates, while a few cells seemed to lack most of these polymers. The uneven distribution of EP fibrils might, however, be an artifact introduced during the preparation of the TEM samples. The EP fibrils were not observed in the control samples prepared without ruthenium red.

\section{Extractions of surface polymers}

Attempts were made to extract the ruthenium-redstaining EP layer from $A$. oligospora by treating liquidgrown mycelia of the fungus with various solutions or enzymes followed by TEM examination. Most of the ruthenium-red-staining EP fibrils were removed by treating the mycelia with a mild sonication $(3 \times 20 \mathrm{~s}$, $4{ }^{\circ} \mathrm{C}$ ) in a Tris buffer (Fig. 1 c). No lysis of the sonicated cells was observed. Washing the mycelium with a strong chaotropic salt solution ( $5 \mathrm{M}-\mathrm{LiCl}$ ) also seemed to remove some of the polymers in the EP layer. However, at least some of the extracellular fibrils remained on the cell surface after this treatment, and they were more densely packed than those in the untreated samples. Washing the mycelia with a buffer containing the thiol reagent DTT did not remove or modify the ultrastructure of the EP layer, as visualized by TEM. Treating the mycelia with $0 \cdot 1 \mathrm{M}-\mathrm{NaOH}$ or with a mixture of SDS-mercaptoethanol- 

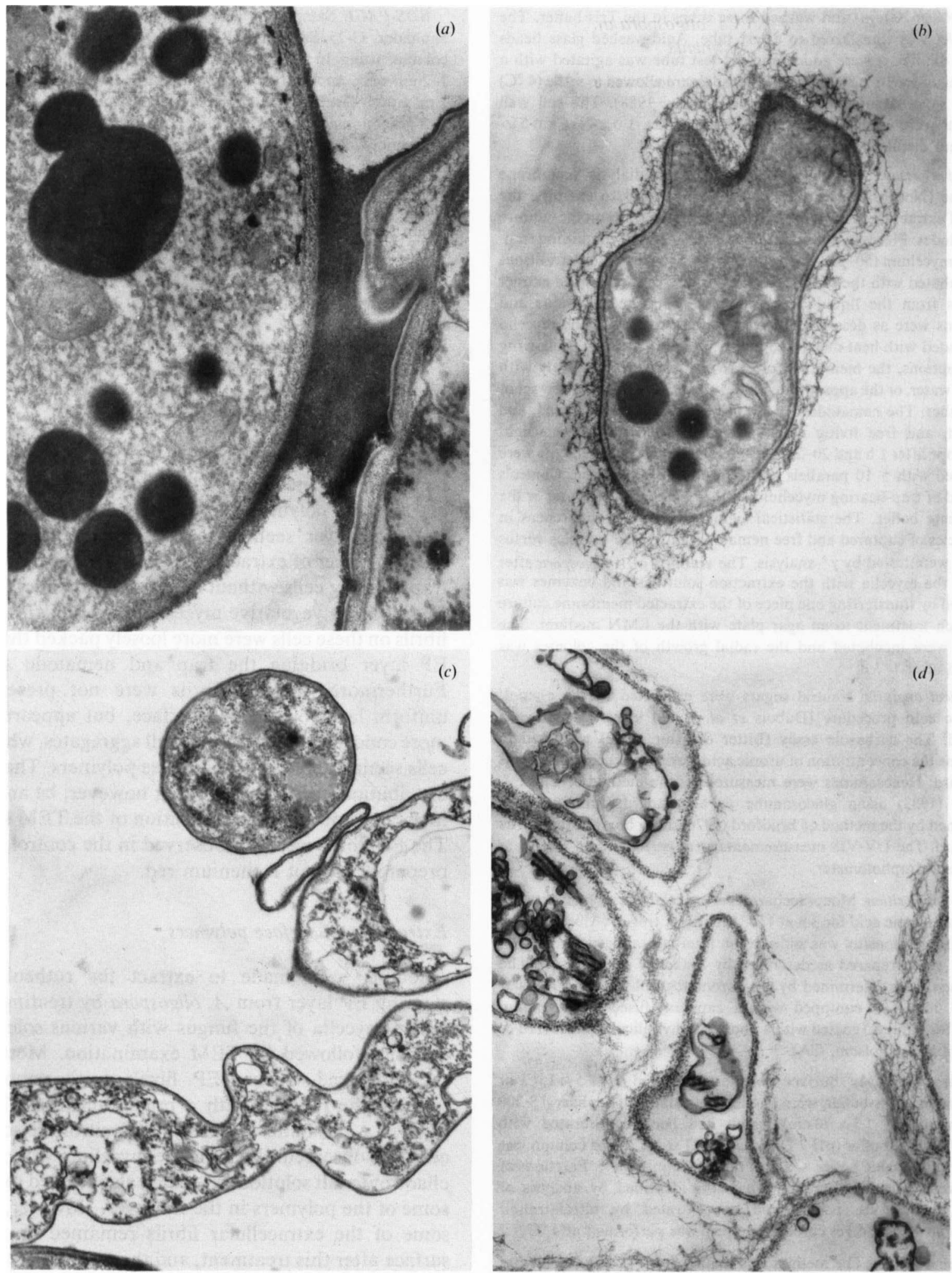

Fig. 1. Transmission electron microscopy using ruthenium red staining of surface polymers of Arthrobotrys oligospora. (a) The fungus (left) adhering to the surface of the nematode Panagrellus redivivus (right). Magnification $\times 20000$. (b) Polymer layer on trap cells of $A$. oligospora present in the absence of the nematode. Magnification $\times 16000$. (c) Removal of extracellular polymers by treating the mycelia with a mild sonication in a Tris-buffer. Magnification $\times 13000$. $(d)$ Modification of the surface polymers by treating the mycelia with Pronase E. Magnification $\times 13000$. 
Table 1. Nematode capture by A. oligospora after various mycelium treatments

A bioassay using a dialysis membrane technique was used. Pieces of dialysis membrane containing trap-bearing mycelium were incubated with the solutions in the table. The membranes were washed with a buffer and nematodes were added. Captured and free nematodes were counted under a light microscope after $1 \mathrm{~h}$ and $20-22 \mathrm{~h}$ of interaction. Controls, using mycelium washed with the appropriate buffer, were in the range of $42-58 \%$ capture at time $1 \mathrm{~h}$, and $87-97 \%$ at $20-22 \mathrm{~h}$. Experiments used 5-10 parallel incubations and were repeated twice.

\begin{tabular}{|c|c|c|c|c|c|c|c|}
\hline \multirow[b]{3}{*}{ Treatment } & \multicolumn{6}{|c|}{$\%$ Captured nematodes } & \multirow[b]{3}{*}{ Viability* } \\
\hline & \multicolumn{3}{|c|}{$1 \mathrm{~h}$} & \multicolumn{3}{|c|}{$20-22 \mathrm{~h}$} & \\
\hline & Mean & SD & $P \dagger$ & Mean & SD & $P$ & \\
\hline DTT & $33 \cdot 3$ & 11.8 & NS & $93 \cdot 4$ & 6.6 & NS & + \\
\hline $1 \mathrm{M}-\mathrm{LiCl}$ & $33 \cdot 1$ & $22 \cdot 0$ & ** & $53 \cdot 2$ & $32 \cdot 7$ & ** & + \\
\hline $5 \mathrm{M}-\mathrm{LiCl}$ & $2 \cdot 4$ & 1.9 & $* * *$ & $2 \cdot 3$ & 1.9 & $* * *$ & $(+)$ \\
\hline $0.1 \mathrm{M}-\mathrm{NaOH}$ & $5 \cdot 1$ & 4.9 & $* * *$ & $0 \cdot 2$ & 0.4 & $* * *$ & - \\
\hline $\begin{array}{l}\text { SDS-Urea- } \\
\text { mercaptoethanol }\end{array}$ & 0.6 & $1 \cdot 3$ & $* * *$ & 0.4 & 0.9 & $* * *$ & - \\
\hline Sonication & $15 \cdot 0$ & $14 \cdot 3$ & $* *$ & $52 \cdot 0$ & $23 \cdot 5$ & $* * *$ & + \\
\hline
\end{tabular}

* Viability was tested by observing the growth of washed mycelia on agar plates. + , no differences in growth rate compared to control sample, $(+)$; growth delayed; - , no growth.

$\dagger P$ values from $\chi^{2}$-tests $(\mathrm{df}=1)$ comparing the frequencies of captured and free nematodes in treated versus control samples. NS $=$ not significant; ${ }^{*}, 0.01<P<0.1 ;{ }^{* *}, 0.001<P \leq 0.01 ; * * *$, $P \leq 0.001$.

urea seemed to remove some of the EP polymers. However, these chemicals also extracted most of the cytoplasm from the cells. None of the enzymes used completely removed the ruthenium red EP layer, but some of them seemed to affect the ultrastructure of the fibrillar polymers. The most notable effect was observed in cells treated with Pronase E. The EP fibrils in those samples came loose from the cell surface (Fig. $1 d$ ). The effects of treatment with cellulase, lyticase or Novozym 234 were less prominent, and the latter two enzymes also led to the degradation of some cell walls. Treatment with mannosidase, glucuronidase and chitinase did not affect the ultrastructure of the EP layer as observed in TEM. The ruthenium-red-staining EP layer was not present on the isolated cell walls of $A$. oligospora. Thus, the EP fibrils were lost during the preparation of cell walls.

\section{Effects on adhesion}

The effects of treating the mycelia of $A$. oligospora with the solutions used to remove the surface polymers on the capture of nematodes were also examined (Table 1). Adhesion of nematodes significantly decreased when the fungus was washed with $\mathrm{LiCl}, 0 \cdot 1 \mathrm{M}-\mathrm{NaOH}$, SDSmercaptoethanol-urea, or when sonicated. However,
Table 2. Nematode capture by A. oligospora after further mycelium treatments

See Table 1 for descriptions of the bioassay, viability test and statistics.

\begin{tabular}{|c|c|c|c|c|c|c|c|}
\hline \multirow[b]{3}{*}{ Treatment } & \multicolumn{6}{|c|}{$\%$ Captured nematodes } & \multirow[b]{3}{*}{ Viability } \\
\hline & \multicolumn{3}{|c|}{$1 \mathrm{~h}$} & \multicolumn{3}{|c|}{$20-22 \mathrm{~h}$} & \\
\hline & Mean & SD & $P$ & Mean & SD & $P$ & \\
\hline $\begin{array}{l}\text { Pronase E } \\
2.9 \mathrm{mg} \mathrm{ml}^{-1}\end{array}$ & $11 \cdot 3$ & $7 \cdot 2$ & $* * *$ & $39 \cdot 0$ & $29 \cdot 3$ & $* * *$ & + \\
\hline $\begin{array}{l}\text { Pronase E } \\
0.3 \mathrm{mg} \mathrm{ml}^{-1}\end{array}$ & $27 \cdot 8$ & $14 \cdot 7$ & $* * *$ & $75 \cdot 7$ & $10 \cdot 3$ & NS & + \\
\hline $\begin{array}{l}\text { Pronase E } \\
2.9 \mathrm{mg} \mathrm{ml}^{-1} \\
\text { (denatured) } \dagger^{\dagger}\end{array}$ & $77 \cdot 2$ & $8 \cdot 5$ & NS & $96 \cdot 9$ & $3 \cdot 1$ & NS & $\mathrm{ND}_{\ddagger}^{+}$ \\
\hline $\begin{array}{l}\text { Lyticase } \\
2 \cdot 7 \mathrm{mg} \mathrm{ml}^{-1}\end{array}$ & $39 \cdot 3$ & $18 \cdot 1$ & $* *$ & $85 \cdot 0$ & $9 \cdot 9$ & $* *$ & + \\
\hline $\begin{array}{l}\text { Lyticase } \\
0.3 \mathrm{mg} \mathrm{ml}^{-1}\end{array}$ & $48 \cdot 2$ & $20 \cdot 2$ & $*$ & $93 \cdot 8$ & 4.9 & NS & + \\
\hline $\begin{array}{l}\text { Lyticase } \\
2 \cdot 7 \mathrm{mg} \mathrm{ml}^{-1} \\
\text { (denatured) }\end{array}$ & $65 \cdot 7$ & $19 \cdot 5$ & NS & 89.9 & $4 \cdot 5$ & NS & ND \\
\hline Glucuronidase & $76 \cdot 3$ & $11 \cdot 0$ & $* *$ & 97.8 & $2 \cdot 4$ & NS & + \\
\hline $\begin{array}{l}\text { Glucuronidase } \\
\text { (denatured) }\end{array}$ & $75 \cdot 7$ & $4 \cdot 7$ & $* *$ & $99 \cdot 3$ & 1.5 & $*$ & ND \\
\hline Mannosidase & $40 \cdot 0$ & $10 \cdot 9$ & $* *$ & $75 \cdot 2$ & $14 \cdot 8$ & ** & $(+)$ \\
\hline $\begin{array}{l}\text { Mannosidase } \\
\text { (denatured) }\end{array}$ & $17 \cdot 2$ & $5 \cdot 2$ & $* * *$ & $74 \cdot 7$ & $7 \cdot 3$ & $* *$ & ND \\
\hline
\end{tabular}

$\dagger$ Enzymes denatured by heating at $90^{\circ} \mathrm{C}$ for $30 \mathrm{~min}$. $\ddagger$ ND, not determined.

experiments observing the growth of the washed mycelium showed that mycelia treated with $\mathrm{NaOH}$ or the SDS mixture were not viable.

Treating the mycelia with Pronase E and lyticase significantly decreased the adhesion of nematodes to the traps of $A$. oligospora (Table 2). No effects were observed using the heat-denatured enzymes, indicating that the effects were due to the activity of the enzymes. The capture of nematodes was also affected after treating the traps with mannosidase or glucuronidase. However, these effects were also observed using the corresponding heat-denatured enzymes.

\section{Chemical composition of surface polymers}

The chemical composition of the surface polymers from A. oligospora extracted with $5 \mathrm{M}-\mathrm{LiCl}$ or sonication, from $\mathrm{T}(+)$ and $\mathrm{T}(-)$ mycelia, was analysed by UV-VIS spectroscopy. All extracts contained neutral sugars, uronic acids and proteins (Table 3 ). The concentrations and proportions of uronic acids (of the total amount of sugars) were somewhat higher in the extracts from the $\mathrm{T}(+)$ than from the $\mathrm{T}(-)$ mycelia. No amino sugars were detected in these extracts. 


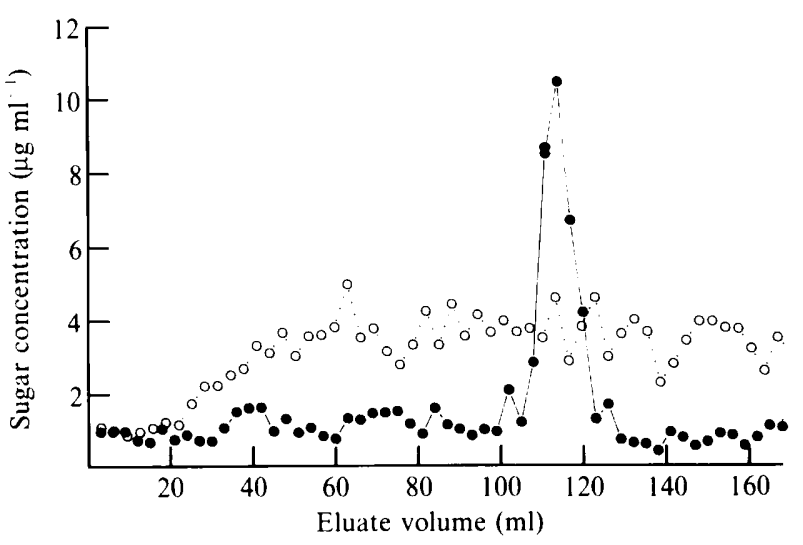

Fig. 2. Fractionation of surface polymers extracted from $A$. oligospora using $5 \mathrm{M}-\mathrm{LiCl}$, according to molecular mass on a Sephacryl S-200 HR column. Extracts were from trap-containing mycelium $[\mathrm{T}(+)](\mathbf{O})$ or from vegetative hyphae $[\mathrm{T}(-)](\mathrm{O})$. The neutral sugar content was determined by the method of Dubois et al., 1956.

Table 3. Contents of neutral sugars, uronic acids and proteins in surface polymer from A. oligospora

The fungus was grown in a liquid culture, with $\mathrm{T}(+)$ and $\mathrm{T}(-)$ designating mycelium with and without nematode-trapping networks, respectively. The polymers were extracted with $5 \mathrm{M}$ $\mathrm{LiCl}$ or by sonication in a $\mathrm{Tris} / \mathrm{HCl}$ buffer, and were concentrated by ultrafiltration. Values are expressed as $\mu \mathrm{g}(\mathrm{mg} \text { dry wt})^{-1}$.

\begin{tabular}{llllll}
\hline \hline & \multicolumn{2}{c}{$5 \mathrm{M}-\mathrm{LiCl}$} & & \multicolumn{2}{c}{ Sonication } \\
\cline { 2 - 3 } \cline { 6 - 6 } Compounds & $\mathrm{T}(+)$ & $\mathrm{T}(-)$ & & $\mathrm{T}(+)$ & $\mathrm{T}(-)$ \\
\hline Neutral sugars & 1.43 & 1.70 & & 2.82 & 2.87 \\
Uronic acids & 0.53 & 0.49 & & 0.47 & 0.22 \\
Proteins & 0.10 & 0.10 & & 6.32 & 5.77 \\
\hline \hline
\end{tabular}

\section{Chromatographic separations}

Gel chromatography revealed major differences in the composition of carbohydrate-containing polymers in extracts from $\mathrm{T}(+)$ and $\mathrm{T}(-)$ mycelia. The $\mathrm{LiCl}$ extracts from the $\mathrm{T}(+)$ culture contained a fraction of carbohydrate-containing polymers with an apparent molecular mass of $22 \mathrm{kDa}$ (estimated from selectivity curves using protein standards) (Fig. 2). This polymer fraction was not detected in $\mathrm{LiCl}$ extracts from $\mathrm{T}(-)$ cells.

The major carbohydrate-containing polymers in the sonication extracts from $\mathrm{T}(+)$ mycelia eluted in the void volume of the column (peak 1, Fig. 3). The molecular masses of the polymers in this fraction are not known, but the exclusion limit for a Dextran polymer of the Sephacryl S-200 gel medium is about $100 \mathrm{kDa}$ (Pharmacia). The overall chemical composition of this polymer fraction was $75 \%$ neutral sugars, $6 \%$ uronic acids and $19 \%$ proteins (by weight), as analysed by UV-VIS spectroscopy. Apart from this fraction, two other carbohydrate-containing fractions (peaks $2 a$ and $2 b$ in Fig. 3), with chromatographic retention times close to

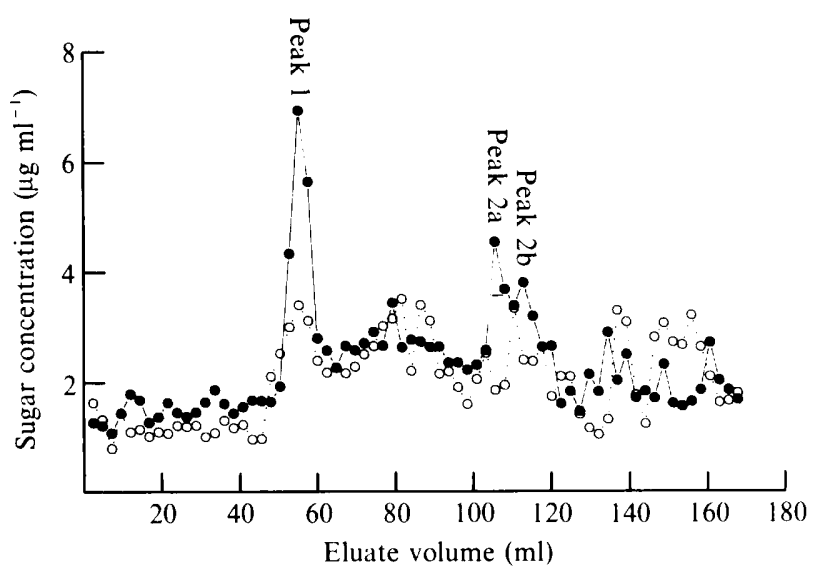

Fig. 3. Fractionation of surface polymers extracted from $A$. oligospora using sonication in a Tris buffer, according to molecular mass, on a Sephacryl S-200 HR column. Extracts were from trap-containing mycelium $[\mathrm{T}(+)](\Theta)$ or from vegetative hyphae $[\mathrm{T}(-)](O)$. The neutral sugar content was determined by the method of Dubois et al., 1956.

Table 4. Composition of neutral sugars in surface polymers from A. oligospora

The fungus was grown in a liquid culture with $\mathrm{T}(+)$ and $\mathrm{T}(-)$ designating mycelium with and without nematode-trapping networks, respectively. The polymers were extracted with $5 \mathrm{M}$ $\mathrm{LiCl}$ or by sonication in a $\mathrm{Tris} / \mathrm{HCl}$ buffer and concentrated by ultrafiltration. Values are expressed as $\mathrm{mol} \%$.

\begin{tabular}{|c|c|c|c|}
\hline Samples & Mannose & Glucose & Galactose \\
\hline \multicolumn{4}{|l|}{$5 \mathrm{M}-\mathrm{LiCl}$ extracts } \\
\hline$T(+)$, total extract & $11 \cdot 2$ & $88 \cdot 8$ & $\mathrm{ND}^{\dagger}$ \\
\hline$T(+)$, peak* & ND & $100 \cdot 0$ & ND \\
\hline $\mathrm{T}(-)$, total extract & $11 \cdot 7$ & $88 \cdot 3$ & ND \\
\hline \multicolumn{4}{|l|}{ Sonication extracts } \\
\hline$T(+)$, total extract & $4 \cdot 8$ & $92 \cdot 2$ & $3 \cdot 3$ \\
\hline $\mathbf{T}(+)$, peak $1^{*}$ & $8 \cdot 3$ & $85 \cdot 5$ & $3 \cdot 3$ \\
\hline$T(+)$, peak $2 \mathrm{a}$ & $4 \cdot 7$ & $90 \cdot 2$ & $5 \cdot 1$ \\
\hline$T(+)$, peak $2 b$ & $4 \cdot 6$ & $92 \cdot 4$ & 3.0 \\
\hline $\mathrm{T}(-)$, total extract & $11 \cdot 3$ & $82 \cdot 5$ & $6 \cdot 2$ \\
\hline $\mathrm{T}(-)$, peak 1 & $25 \cdot 9$ & $56 \cdot 3$ & $17 \cdot 8$ \\
\hline $\mathrm{T}(-)$, peak $2 \mathrm{a}$ & $8 \cdot 8$ & $74 \cdot 0$ & $17 \cdot 1$ \\
\hline $\mathrm{T}(-)$, peak $2 \mathrm{~b}$ & 8.9 & $67 \cdot 5$ & $23 \cdot 5$ \\
\hline
\end{tabular}

* Peaks are shown in gel chromatograms, Figs. 2 and 3. $\dagger$ ND, not detected.

the major peak in the $\mathrm{T}(+) \mathrm{LiCl}$ extract, were also detected in the $\mathrm{T}(+)$ extracts. Sonication extracts from the $\mathrm{T}(-)$ mycelium contained considerably lower amounts of the carbohydrate containing polymers detected in the $T(+)$ extracts.

\section{Carbohydrate analysis}

Gas chromatographic analysis showed that glucose was the major neutral sugar component of the surface polymers extracted with $5 \mathrm{M}-\mathrm{LiCl}$ (Table 4). The crude $\mathrm{LiCl}$ extract also contained minor amounts of mannose. There were no differences in the composition of neutral 
(a)

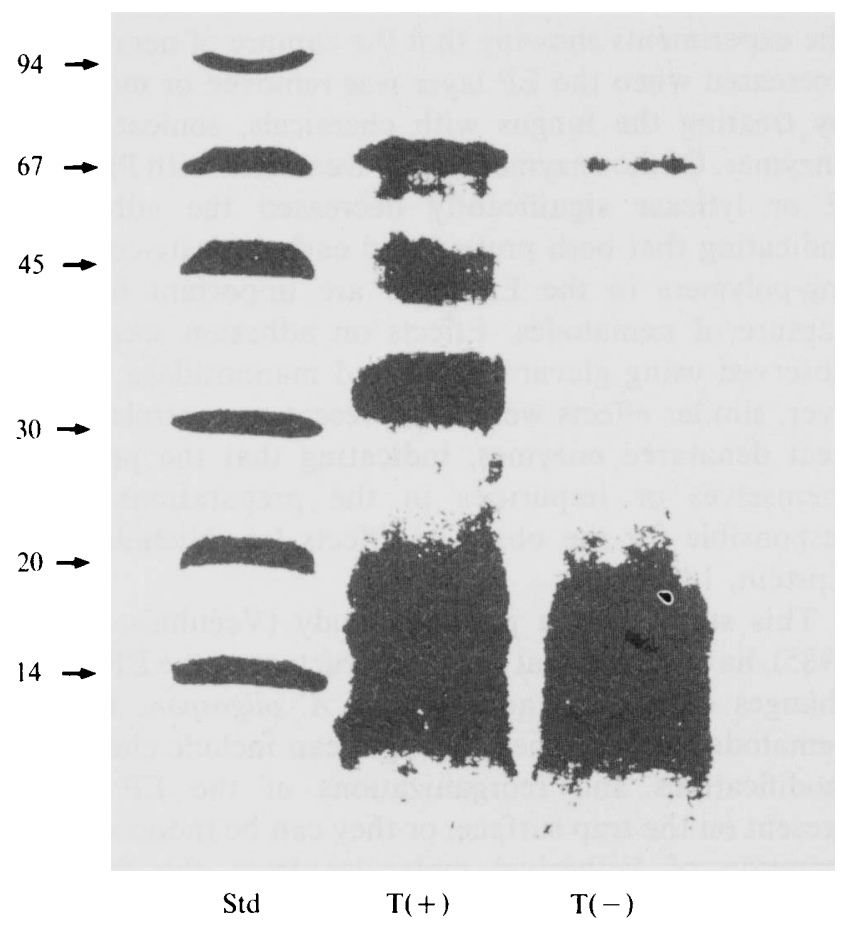

(b)

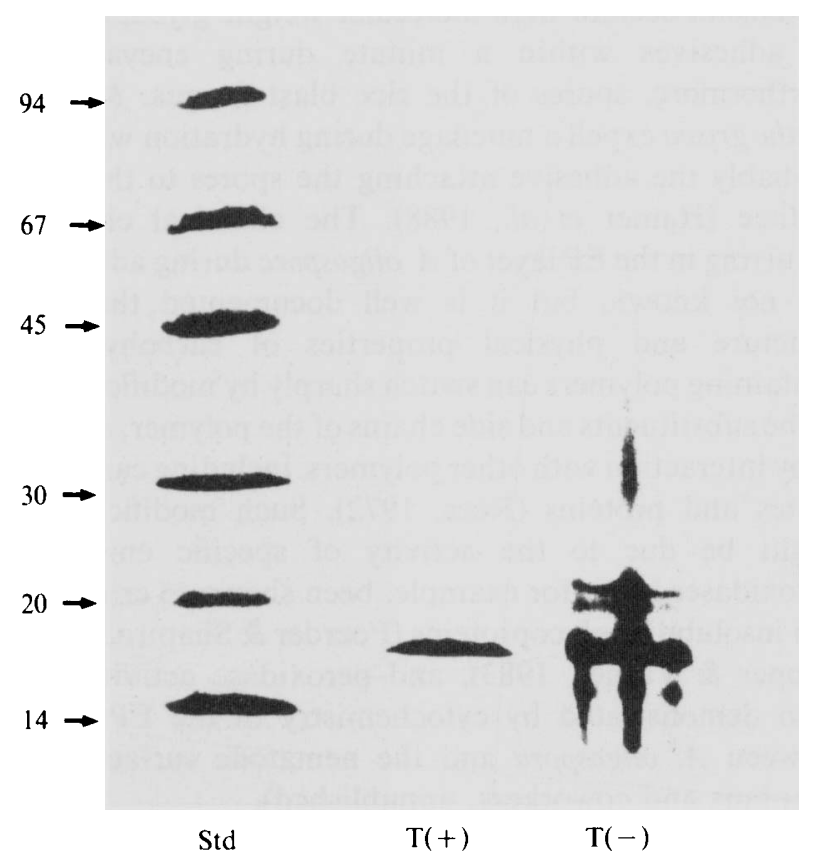

Fig. 4. SDS-PAGE of surface polymers extracted from $A$. oligospora using $(a) 5 \mathrm{M}-\mathrm{LiCl}$; and $(b)$ sonication in Tris buffer. Extracts were from trap-containing mycelium $[\mathrm{T}(+)]$ or from vegetative hyphae $[\mathrm{T}(-)]$. The gels were stained with Coomassie Brilliant Blue, and molecular masses $(\mathrm{kDa})$ of standard proteins $(\mathrm{Std})$ are indicated.

sugars in the extracts from the $T(+)$ and $T(-)$ mycelium. The carbohydrate polymer in the $\mathrm{LiCl}$ extract separated by gel chromatography contained glucose as the only detected neutral sugar.
The crude sonication extracts as well as the polymers fractionated by gel chromatography contained glucose, mannose and galactose as neutral sugars (Table 3 ). The major peak from the gel fltration had a somewhat lower proportion of glucose than the unfractionated (crude) extracts. The polymers extracted from the $\mathrm{T}(+)$ mycelium had a higher proportion of glucose than the corresponding fractions from the $\mathrm{T}(-)$ mycelium.

\section{Pronase digestion}

Pronase E treatment of surface polymers, extracted by sonication from $\mathrm{T}(+)$ mycelium, indicated that the high molecular weight polymer(s) eluting in the void volume was resistant to protease degradation. Minor changes were, however, observed in the chemical composition of the polymer(s) after the treatment, since chemical analysis revealed a content of $74 \%$ (by wt) neutral sugars, $13 \%$ uronic acids and $13 \%$ proteins (cf. above). The two other peaks present in the untreated $\mathrm{T}(+)$ extracts (peak $2 a$ and $2 b$, in Fig. 3) were degraded by the added protease.

\section{Gel electrophoresis}

SDS-PAGE of surface polymers extracted with $5 \mathrm{M}-\mathrm{LiCl}$ showed the presence of several proteins with molecular masses below $70 \mathrm{kDa}$ (Fig. $4 a$ ). At least one of the major bands, with an estimated molecular mass of $32 \mathrm{kDa}$ in extracts from $\mathrm{T}(+)$ mycelium was not detected in the $\mathrm{T}(-)$ mycelium. The patterns of proteins were less complex in the sonication extracts, as visualized by the Coomassie Blue staining (Fig. $4 b$ ). The major band in both $\mathrm{T}(+)$ and $\mathrm{T}(-)$ sonication extracts corresponded to a protein with a molecular mass of $16 \mathrm{kDa}$. Notably, the total amount of protein (as estimated by UV absorption) in the $\mathrm{T}(+)$ lane was about four times less than in the $\mathrm{T}(-)$ lane, which indicates that the amount of the $16 \mathrm{kDa}$ protein was higher in the $\mathrm{T}(+)$ compared to the $\mathrm{T}(-)$ sample.

\section{Discussion}

The mycelium of $A$. oligospora was surrounded by a layer of extracellular polymer which stained with ruthenium red, indicating that the layer consisted of carbohydratecontaining polymers. Ruthenium red complexes with carboxyl or hydroxyl groups in polymers carrying a high charge density, usually acidic polysaccharides, and has been widely used to locate polysaccharides in microorganisms (Luft, 1971; Handley et al., 1988; Marrie \& Costerton, 1981). However, it has also been reported that 
neutral polysaccharides such as dextran stains with ruthenium red (Brooker, 1979).

Sonication of the mycelium removed most of the ruthenium-red-staining fibrils from the cell surface. It is not known whether this treatment dissolves the EP layer by breaking strategic bonds between the polymers and the cell walls or by disentangling the large macromolecules. Sonication can degrade large molecules (Freifelder, 1982), so polymers extracted with this method might not be intact. Extraction with $\mathrm{LiCl}$ seemed to remove different surface polymers from sonication, since the chemical composition of these extracts was quite different, and TEM analysis showed that at least some of the long chain carbohydrate fibrils remained on the cell surface after $\mathrm{LiCl}$ extraction. The polymers extracted with $\mathrm{LiCl}$ might represent more tightly bound surface polymers not extracted or dissolved by sonication. However, the exact localization of the proteins and carbohydrate polymers in the two extracts cannot be determined with the methods used.

Gel chromatography of the extracted surface polymers showed that the main carbohydrate-containing polymers in the EP layer were long chains of neutral sugars, uronic acids and proteins. It is not known whether this fraction contained one or several carbohydrate polymers. Since this polymer fraction was almost completely resistant to Pronase E treatment, it probably makes up the PronaseE-resistant fibrils observed in the TEM samples treated with this enzyme. The high-molecular-weight polymers could either be polysaccharides or glycoproteins. Glucan microfibrils have been identified in the EP (mucus) layer of e.g. Schizophyllum commune (Wessels et al., 1972) and Conidiobolus obscurus (Latgé et al., 1986), but the EP fibrils of $A$. oligospora are probably not glucans, since the fibrils were resistant to treatments with enzyme preparations containing glucanase activity. The main component in the mucus isolated from the spores of Colletotrichum graminicola was a glycoprotein eluting in the void volume of a Sephacryl S-200 medium (Ramadoss et al., 1985). However, the proportion of proteins in this polymer fraction was considerably higher, and the composition of neutral sugars was different from that of the corresponding polymers isolated from $A$. oligospora. Furthermore, in contrast to the polymers isolated from $A$. oligospora, the polymers from C. graminicola were sensitive to Pronase E digestion. Further purification of the high-molecular-weight polymers is, however, needed before the chemical structure can be examined in more detail.

The differences in carbohydrate and protein composition between surface polymers extracted from trapbearing mycelium and vegetative hyphae of $A$. oligospora suggest that these polymers are involved in the adhesion and infection of nematodes. The importance of EP components in adhesion was more directly suggested in the experiments showing that the capture of nematodes decreased when the EP layer was removed or modified by treating the fungus with chemicals, sonication or enzymes. Of the enzymes tested, treatment with Pronase E or lyticase significantly decreased the adhesion, indicating that both protein and carbohydrate-containing-polymers in the EP layer are important for the capture of nematodes. Effects on adhesion were also observed using glucuronidase and mannosidase. However, similar effects were also present in controls using heat denatured enzymes, indicating that the proteins themselves or impurities in the preparations were responsible for the observed effects (cf. Nicholson \& Epstein, 1990).

This study, and a previous study (Veenhuis et al., 1985), have shown that the ultrastructure of the EP layer changes during the adhesion of $\boldsymbol{A}$. oligospora to the nematode surface. These changes can include chemical modifications and reorganizations of the EP layer present on the trap surface, or they can be induced by a secretion of 'adhesive' molecules from the fungus. Gubler \& Hardham (1988), using monoclonal antibodies, elegantly demonstrated that zoospores of Phytophthora cinnamomi secrete high-molecular-weight glycoproteins as adhesives within a minute during encystment. Furthermore, spores of the rice blast fungus, Magnaporthe grisea expell a mucilage during hydration which is probably the adhesive attaching the spores to the host surface (Hamer et al., 1988). The chemical changes occurring in the EP layer of $A$. oligospora during adhesion are not known, but it is well documented that the structure and physical properties of carbohydratecontaining polymers can switch sharply by modifications of the substituents and side chains of the polymer, as well as by interaction with other polymers, including carbohydrates and proteins (Rees, 1972). Such modifications might be due to the activity of specific enzymes. Peroxidases have, for example, been shown to crosslink and insolubilize glycoproteins (Foerder \& Shapiro, 1977; Cooper \& Varner, 1983), and peroxidase activity has been demonstrated by cytochemistry in the EP layer between $A$. oligospora and the nematode surface ( $M$. Veenhuis and coworkers, unpublished).

Previous studies have shown that the adhesion of nematodes to $A$. oligospora can be inhibited by treating the fungus with $N$-acetylgalactosamine (GalNAc)(Nordbring-Hertz \& Mattiasson, 1979). The lectin has been purified (Borrebaeck et al., 1984), and localized by immunogold techniques to the cell surface of the fungus (B. Nordbring-Hertz and coworkers, unpublished). The question arises as to how the lectin is involved in the adhesion and in the ultrastructural changes occurring in the EP layer. It is possible that the adhesion between the 
nematode and $A$. oligospora is a two step process. The initial step could be a recognition event involving an interaction between the lectin and a receptor on the nematode surface (Borrebaeck et al., 1985). This interaction could trigger the reorganisation of the surface polymer layer of the trap cells, leading to the firm binding of the nematode.

The presence of an EP layer on vegetative hyphae with no trap-bearing cells suggests that such polymers might have biological functions apart from the adhesion to, and infection of, nematodes. It has been shown that the mucus layer of some plant pathogenic fungi contain extracellular enzymes that might be important for the penetration of the host cells (Ramadoss et al., 1985; Nicholson et al., 1988). The presence of uronic acids and the high affinity for ruthenium red indicate that the EP layer of $A$. oligospora is anionic, as are many extracellular polymers isolated from bacteria (Sutherland, 1989). Such polymers can both attract cations and charged organic molecules from the surrounding environment and protect the cells from hydrolytic enzymes and other antimicrobial agents (Costerton et al., 1981). It has been shown that EP layers of spores from $C$. graminicola contain compounds that protect fungal mycelium from desiccation and the toxic effects of phenolic compounds (Nicholson \& Moraes, 1980; Nicholson et al., 1986).

This study was supported by grants from the Swedish Natural Science Research Council to A.T. and B.N.H. We thank Eva Winkvist for technical assistance. We are grateful to Lena Sandell, Dr Claes von Mecklenburg and Dr Erik Carlemalm at the Electron Microscopy Unit, Lund University, for valuable help with the electron microscopy.

\section{References}

Albersheim, P., Nevins, D. J., English, P. D. \& KarR, A. (1967). A method for the analysis of sugars in plant cell-wall polysaccharides by gas-liquid chromatography. Carbohydrate Research 5, 340-345.

Beever, R. E., ReDGwell, R. J. \& Dempsey, G. P. (1979). Purification and chemical characterization of the rodlet layer of Neurospora crassa. Journal of Bacteriology 140, 1063-1070.

BITTER, T. \& MUIR, H. M. (1962). A modified uronic acid and carbazole reaction. Analytical Biochemistry 4, 330-334.

Blakeney, A. B., Harris, P. J., Henry, R. J. \& Stone, B. A. (1983). A simple and rapid preparation of alditol acetates for monosaccharide analysis. Carbohydrate Research 113, 291-299.

Borrebaeck, C. A. K., Mattiasson, B. \& Nordbring-Hertz, B. (1984). Isolation and partial characterization of a carbohydratebinding protein from a nematode-trapping fungus. Journal of Bacteriology 159, 53-56.

Borrebaeck, C. A. K., Mattiasson, B. \& Nordbring-Hertz, B. (1985). A fungal lectin and its apparent receptors on a nematode surface. FEMS Microbiology Letters 27, 35-39.

BRADFORD, M. M. (1976). A rapid and sensitive method for the quantitation of microgram quantities of protein utilizing the principle of protein-dye binding. Analytical Biochemistry 72, 248-254.
BROOKER, B. E. (1979). Electron microscopy of the dextrans produced by lactic acid bacteria. In Microbial Polysaccharides and Polysaccharidases, Special Publication no. 3 of the Society for General Microbiology, pp. 85-115. Edited by R. C. W. Berkeley, G. W. Gooday \& D. C. Ellwood. London: Academic Press.

Catley, B. J. (1988). Isolation and analysis of cell walls. In Yeast : a Practical Approach, pp. 163-183. Edited by I. Campbell \& J. H. Duffus. Oxford: IRL Press.

Chaffin, W. L. \& Stocco, D. M. (1983). Cell wall proteins of Candida albicans. Canadian Journal of Microbiology 29, 1438-1444.

Chattaway, F. W., Shenolikar, S. \& Barlow, A. J. E. (1974). The release of acid phosphatase and polysaccharide- and proteincontaining components from the surface of the dimorphic-forms of Candida albicans by treatment with dithiothreitol. Journal of General Microbiology 83, 423-425.

Claverie-Martin, F., Diaz-Torres, M. R. \& Geoghegan, M. J. (1986). Chemical composition and electron microscopy of the rodlet layer of Aspergillus nidulans conidia. Current Microbiology 14, 221-225.

COOPER, J. B. \& VARNER, J. E. (1983). Insolubilization of hydroxyproline-rich cell wall glycoprotein in aerated carrot slices. Biochemical and Biophysical Research Communications 112, 161-167.

Costerton, J. W., IRvin, R. T. \& Cheng, K.-J. (1981). The role of bacterial surface structures in pathogenesis. CRC Critical Reviews in Microbiology 8, 303-338.

Dubois, M., Gilles, K. A., Hamilton, J. K., Rebers, P. A. \& Smith, F. (1956). Colorimetric method for determination of sugars and related substances. Analytical Chemistry 28, 350-356.

Elson, L. A. \& Morgan, W. T. J. (1933). A colorimetric method for the determination of glucosamine and chondrosamine. Biochemical Journal 27, 1824-1828.

FoERDER, C. A. \& ShapIRo, B. M. (1977). Release of ovoperoxidase from sea urchin eggs hardens the fertilization membrane with tyrosine crosslinks. Proceedings of the National Academy of Sciences of the United States of America 74, 4214-4218.

FREIFELDER, D. (1982). Hydrodynamic shear and sonic degradation. In Physical Biochemistry. Applications to Biochemistry and Molecular Biology, pp. 685-688. San Francisco: W. H. Freeman and Company.

Friman, E., Olsson, S. \& Nordbring-HerTZ, B. (1985). Heavy trapformation by Arthrobotrys oligospora in liquid culture. FEMS Microbiology Ecology 31, 17-21.

Gold, R. E. \& MEndGen, K. (1984). Cytology of basidiospore germination, penetration, and early colonization of Phaseolus vulgaris by Uromyces appendiculatus var. appendiculatus. Canadian Journal of Botany 62, 1989-2002.

GUBLER, F. \& HARDHAM, A. R. (1988). Secretion of adhesive material during encystment of Phytophthora cinnamomi zoospores, characterized by immunogold labelling with monoclonal antibodies to components of peripheral vesicles. Journal of Cell Science 90, 225-235.

Hamer, J. E., Howard, R. J., Chumley, F. G. \& Valent, B. (1988). A mechanism for surface attachment in spores of a plant pathogenic fungus. Science 239, 288-290.

Handley, P. S., Hargreaves, J. \& Harty, D. W. S. (1988). Ruthenium red staining reveals surface fibrils and a layer external to the cell wall in Streptococcus salivarius $\mathrm{HB}$ and adhesion deficient mutants. Journal of General Microbiology 134, 3165-3172.

HyDE, K. D. \& JoNES, E. B. G. (1989). Observation on ascospore morphology in marine fungi and their attachment to surfaces. Botanica Marina 32, 205-218.

KeNNEDY, M. J. (1990). Models for studying the role of fungal attachment in colonization and pathogenesis. Mycopathologia 109, 123-137.

Latgé, J.-P., Cole, G. T., Horisberger, M. \& Prévost, M.-C. (1986). Ultrastructure and chemical composition of the ballastospore wall of Conidiobolus obscurus. Experimental Mycology 10, 99-113.

LuFT, J. H. (1971). Ruthenium red and violet I. Chemistry, purification, methods of use for electron microscopy and mechanism of action. Anatomical Record 171, 347-368.

MARRIE, T. J. \& Costerton, J. W. (1981). The ultrastructure of Candida albicans infections. Canadian Journal of Microbiology 27, 1156-1164. 
Mims, C. W. \& Richardson, E. A. (1989). Ultrastructure of appressorium development by basidiospore germlings of the rust fungus Gymnosporangium juniperi-virginianae. Protoplasma 148, 111-119.

Nicholson, R. L. \& EPSTEIN, L. (1991). Adhesion of fungi to the plant surface: prerequisite for pathogenesis. In The Fungal Spore and Disease Initiation in Plants and Animals. Edited by C. T. Cole \& H. C. Hoch. New York: Plenum Press.

Nicholson, R. L. \& MoraEs, W. B. C. (1980). Survival of Colletotrichum graminicola: importance of the spore matrix. Phytopathology 70, 255-261.

Nicholson, R. L., Butler, L. G. \& Asquith, T. N. (1986). Glycoproteins from Colletotrichum graminicola that bind phenols: implications for survival and virulence of phytopathogenic fungi. Phytopathology 76, 1315-1318.

Nicholson, R. L., Yoshioka, H., Yamaoka, N. \& Kunoh, H. (1988). Preparation of the infection court by Erysiphe graminis II. Release of esterase enzyme from conidia in relation to a contact stimulus. Experimental Mycology 12, 336-349.

Nordbring-Hertz, B. \& Mattiasson, B. (1979). Action of a nematode-trapping fungus shows lectin-mediated host-microorganism interaction. Nature, London 281, 477-479.

Nordbring-Hertz, B., VeEnhuIs, M. \& HARder, W. (1984). Dialysis membrane technique for ultrastructural studies of microbial interactions. Applied and Environmental Microbiology 45, 290-293.

NoRDBRING-HerTZ, B. (1988). Ecology and recognition in the nematode-nematophagous fungus system. In Advances in Microbial Ecology, vol. 10, pp. 81-114. Edited by K. C. Marshall. New York: Plenum Press.

Nordbring-Hertz, B. \& Mattiasson, B. (1979). Action of a nematode-trapping fungus shows lectin-mediated host-microorganism interaction. Nature, London 281, 477-479.

Nordbring-HertZ, B., VeEnhuis, M. \& HARDER, W. (1984). Dialysis membrane technique for ultrastructural studies of microbial interactions. Applied and Environmental Microbiology 45, 290-293.

ONYILE, A. B., Edwards, H. H. \& Gessner, R. V. (1982). Adhesive material of the hyphopodia of Buergenerula spartinae. Mycologia 74, 777-784.

Peberdy, J. F. (1985). Mycolytic enzymes. In Fungal Protoplasts. Applications in Biochemistry and Genetics, pp. 31-44. Edited by J. F. Peberdy \& L. Ferenczy. New York: Marcel Dekker, Inc.

Ponton, J. \& JoNes, J. M. (1986). Analysis of cell wall extracts of
Candida albicans by sodium dodecyl sulfate-polyacrylamide gel electrophoresis and western blot techniques. Infection and Immunity 53, 565-572.

Ramadoss, C. S., Uhlig, J., Carlson, D. M., Butler, L. G. \& Nicholson, R. L. (1985). Composition of the mucilaginous spore matrix of Colletotrichum graminicola, a pathogen of corn, sorghum, and other grasses. Journal of Agricultural and Food Chemistry 33, 728732.

REES, D. A. (1972). Shapely polysaccharides. Biochemical Journal 126, 257-273.

SPIRO, R. G. (1966). Analysis of sugars found in glycoproteins. Methods in Enzymology 8, 3-25.

SUTHERLAND, I. W. (1989). Microbial polysaccharides - a comparison with eukaryotic polymers. In Mucus and Related Topics, Symposia of the Society for Experimental Biology, no. XLIII, pp. 389-402. Edited by E. Chantler \& N. A. Ratcliffe. Cambridge: The Company of Biologists Ltd.

TaYlor, I. E. P. \& Cameron, D. S. (1973). Preparation and quantitative analysis of fungal cell walls: strategy and tactics. Annual Review of Microbiology 27, 243-259.

TeEPE, H., BötTGE, J.-A. \& Wöstemeyer, J. (1988). Isolation and electrophoretic analysis of surface proteins of the zygomycete Absidia glauca. FEBS Letters 234, 100-106.

Tronchin, G., Poulain, D. \& Vernes, A. (1984). Cytochemical and ultrastructural studies of Candida albicans III. Evidence for modification of the cell wall coat during adherence to human and buccal epithelial cells. Archives of Microbiology 139, 221-224.

Veenhuis, M., Nordbring-Hertz, B. \& Harder, W. (1985). An electron-microscopical analysis of capture and initial stages of penetration of nematodes by Arthrobotrys oligospora. Antonie van Leeuwenhoek 51, 385-398.

Wessels, J. G. H. \& Sietsma, J. H. (1981). Fungal cell walls: a survey. In Plant Carbohydrates II: Extracellular Carbohydrates pp. 352-394. Edited by W. Tanner \& F. A. Loewus. Berlin: Springer Verlag.

Wessels, J. G. H., KReger, D. R., Marchant, R., Regensburg, B. A. \& DeVRIES, O. M. H. (1972). Chemical and morphological characterization of the hyphal cell wall surface of the basidiomycete Schizophyllum commune. Biochimica et Biophysica Acta 273, 346358.

Wu-Yuan, C. D. \& Hashimoto, T. (1977). Architecture and chemistry of microconidial walls of Trichophyton mentagrophytes. Journal of Bacteriology 129, 1584-1592. 